\title{
On-farm phenotypic characterization of indigenous sheep and its crossbreed with exotic Awassi in selected district of South Wollo, Amhara, Ethiopia
}

\author{
NURLIGN MOHAMMED ${ }^{1, \vartheta}$, KEFYALEW ALEMAYEHU ${ }^{1}$, TESFAYE GETACHEW ${ }^{2}$ \\ ${ }^{1}$ College of Agriculture and Environmental Sciences, Bahir Dar University, P.O. Box 79, Bahir Dar, Ethiopia. ^email: mnurlign@ gmail.com \\ ${ }^{2}$ Ethiopian Biodiversity Institute, Addis Ababa, Ethiopia
}

Manuscript received: 15 March 2017. Revision accepted: 4 April 2017.

\begin{abstract}
Mohammed N, Alemayehu K, Getachew T. 2017. On-farm phenotypic characterization of indigenous sheep and its crossbreed with exotic Awassi in selected district of South Wollo, Amhara, Ethiopia. Trop Drylands 1: 1-12. Selection of genetic resources is important to select desirable traits in breeding programs to improve the quality and production of livestock including sheep. This study aimed to investigate the phenotypic diversity of indigenous sheep breeds in selected districts of south Wollo highlands and to assess the effect of crossbreeding of Wollo sheep with exotic Awassi sheep on growth and morphological characters under stallholder management of eastern Amhara, Ethiopia. Three districts were selected purposely based on their sheep flock size, sheep production potential and their contribution to the farmers. Bodyweight and linear body measurements were taken from 525 mature indigenous sheep and Local $\mathrm{x}$ Awassi crossbred. Body weight and most of the linear body measurements of indigenous sheep population were significantly affected by the district. Crossbred had significantly higher body weight and body measurements than indigenous sheep in Legambo district. Sex had a significant effect on body weight, wither height, and rump height for Awassi crossbred. Body weight and all linear body measurements were significantly influenced by age group. Sex and age group interaction significantly affected body weight and most linear measurements of indigenous sheep, and significantly affected wither height and rump height of local x Awassi crossbred. There was a positive and strong correlation between body weight and chest girth of indigenous female sheep as well as between rump height, body length, chest girth, wither height, and body weight of indigenous male sheep. Positive and strong correlation between body weight and chest girth was observed for Awassi crossbred females. Chest girth and body length for indigenous and local x Awassi crossbred sheep could be used for the prediction of body weight. The body weight of local x Awassi crossbred $(28.75 \pm 0.49 \mathrm{~kg})$ was higher than the indigenous sheep $(22.19 \pm 0.41 \mathrm{~kg})$ in Legambo district. In conclusion, indigenous sheep have potential for improving livelihood and economy of smallholder farmers using crossbred in the study areas.
\end{abstract}

Keywords: Awassi, characterization, crossbred, indigenous sheep

\section{INTRODUCTION}

Genetic diversity provides raw materials for breed improvement in livestock rearing to adapt to changing environments and demands. Information on the origin and history of animal genetic resources (AnGR) is essential to design strategies for sustainable livestock management (Ajmone-Marsan et al. 2010; Felius et al. 2015). Therefore, the aspect of genetic resources is important particularly for the countries with large production of livestock, including sheep. The top five countries by sheep population from the world are China, Australia, India, Iran and Nigeria by 202 million, 72.6 million, 63 million, 50.2 million and 40.6 million sheep population, respectively (FAOSTAT 2014). According to FAOSTAT (2014) Africa has 340.5 million sheep population and the $2^{\text {nd }}$ largest continent next to Asia by sheep population.

Ethiopia is home to at least 14 traditional sheep populations and nine breeds (Gizaw et al. 2007). From 28.89 million sheep population in the country, about $72.84 \%$ are females, and about $27.16 \%$ are males. From the total number of sheep, $99.78 \%$ are indigenous breeds and the rest are improved sheep (CSA 2016). At the national level, small ruminant accounts for about $90 \%$ of the live animal/meat and $92 \%$ of skin and hide export trade value (Asmare 2010). Sheep rearing in Ethiopia serves as a means of risk mitigation during crop failures, property security, monetary saving and investment, in addition to many other socio-economic and cultural functions. Sheep have special features like efficient utilization of marginal and small plots of land, short generation length, high reproductive rate, low risk of investment and more production per unit of investment as compared with cattle.

Urbanization and growing human population in Ethiopia resulted in increased domestic demand for sheep meat, which also offers a significant incentive for marketoriented production. It is very vital to improve sheep productivity in order to satisfy the large population of the country estimated at 81 million with $2.7 \%$ annual growth rate (AMFI 2010). The transfer of successful animal breeding schemes from developed countries also proved to be difficult or impossible in many instances because such schemes are high-tech operations involving sophisticated methods of measuring and evaluating animals, biotechnologies, very high level of organization and high 
level of input of capital and labor (Kosgey et al. 2006; Kosgey and Okeyo 2007).

The Ethiopian Sheep and Goat Productivity Improvement Program (ESGPIP) took the responsibility for importation of improved genotypes, multiplication of purebred, crossing with indigenous sheep and distribution of both crossbred and pure exotic animals to sheep producers especially for Dorper sheep and Boer goat. The sheep crossbreeding project started with various exotic wool breeds. Government bodies were responsible for importing; multiplication and dissemination of Hampshire, Corriedale, Dorper, Merino and Awassi. The two ranches of Debre Birhan and Amedguya were the main actors, particularly for Awassi sheep multiplication and dissemination. Initially, 50 Corriedale, 6 Hampshire and 6 Romney exotic rams were introduced. However, the exotic breeds were later abandoned because they were not accepted by the farmers as the breeds did not meet farmers' phenotypic preferences for horns and tails. In 1980, the Awassi breed, which has a similar phenotypic appearance to the local sheep, was introduced from Israel and has been well accepted by producers (Gizaw and Getachew 2009). In 1980, Awassi sheep were introduced from Israel and kept at Debre Birhan Sheep Breeding and Multiplication Center (DBSBMC) and Amed Guya Sheep Breeding and Multiplication Center (AGSBMC). There were also continuous importations of pure-bred Awassi sheep totaling 45 (ram and ewe lambs). The two government farms have been engaged in multiplication and distribution of crossbred rams to farmers at a subsidized price. In 2011, about 170 pure Awassi sheep were imported from Israel to start again crossbreeding in the farms (Getachew et al. 2016).

The usefulness of characterization of the phenotypic and the genotype of the indigenous sheep breeds (types) is not in doubt to overcome the abovementioned problem. Classification of the breed is the basis for different sheep breed improvement strategies and sheep productivity schemes. Breed diversity is high in peripheral and remote areas of the country (Gizaw et al. 2008) due to less human intervention for crossing. Similarly, sheep are adapted to various ecological niches and the differing needs and preferences of their breeders who belong to different ethnic communities. High phenotypic diversity was observed for morphological characters on sheep found in the country (Gizaw et al. 2007) and the significance within and between breeds.

Animal live body weight is an important feature, but can hardly still be measured in rural areas due to lack of reasonable accurate scales. Therefore, farmers have to rely on questionable estimates of the body weights of their sheep, leading to inaccuracies in decision making. The most important method of weighing animals without scale is to regress body weight to body characteristics, which can be measured readily. Body measurements have been used to predict body weight by several authors in many breeds of sheep (Sowande and Sobola 2007; Cankaya 2008; Abera et al. 2016).

Ethiopia has a varied sheep population of about 14 sheep types in four major groups, i.e. sub-alpine short fat- tailed, highland long fat-tailed, lowland fat-rumped/tailed and lowland thin-tailed (Gizaw et al. 2008). The sub-alpine short fat-tailed group which consists of Menz, Tikur, and Wollo and Simien sheep types is predominantly found in the central and northern highlands at an altitude of above $2500 \mathrm{~m}$. In this area, sheep are mainly reared for income generation from the sale of lambs at market age although they are also important as a source of food, manure and socio-cultural benefits (Gizaw et al. 2008; Getachew et al. 2010).

On regional scale of Ethiopia, Amhara National Regional State has 9.80 million sheep (CSA 2016) with South Wollo zone alone having 1.86 million sheep, making it the zone with the largest sheep population in Amhara region (CSA 2016). This study aimed to investigate the phenotypic diversity of indigenous sheep breeds in selected districts of South Wollo highlands and to assess the effect of crossbreeding of Wollo sheep with Awassi on growth and morphological characters under stakeholder management.

\section{MATERIALS AND METHODS}

\section{Study area}

The study was conducted in South Wollo zone which is one of 10 zones and one special district in the Amhara Region of Ethiopia. South Wollo is bordered on the south by North Shoa and Oromia Region, on the west by East Gojjam, on the northwest by South Gonder, on the north by North Wollo, on the northeast by Afar Region, and on the east by the Oromia zone and Argobba special district. Its highest point is Mount Amba Ferit. Dessie is the capital city of South Wollo. Based on the 2007 Census conducted by the Central Statistical Agency of Ethiopia (CSA 2008), this zone has a total population of $2,518,862$, with an area of 17,067.45 square kilometers. South Wollo zone has 22 districts; and three districts from these were selected for this study, namely Wogide (Wegde), Borena (Debresina), and Legambo (Figure 1; Table 1).

\section{Sampling techniques}

Three districts in South Wollo were selected purposely based on their sheep flock size, sheep production potential and their contribution to the farmers. To improve body weight and coarse wool production of indigenous Ethiopian sheep, crossbreeding with the Awassi breed imported from Israel is a common practice at Debre Birhan and Amed Guya sheep improvement stations (Lemma et al. 2014). On-farm Awassi x local crossbreeding was started in 1997 by Debre Birhan Agriculture Research Center (DBARC) aiming to evaluate the performance of crossbred sheep under farmer management. The project was carried out in three villages; Serity, Negasi-Amba and Chiro. Chiro was located in South Wollo administrative zone of the Amhara regional state (Getachew et al. 2015). There were 29 participating farmers in Legambo district of Chiro village. Kebele, the lower administrative hierarchy in Ethiopia, was selected considering the density of sheep types. The actual survey included a single visit to a sampling site during 
which quantitative measurements were made on mature sheep. From each district, three kebele (total of nine kebele) were selected.

According to FAO (2012), physical measurements should be taken only from a representative set of adult animals (as judged by dentition): about 100-300 females and 10-30 males. Body weight and linear measurements were taken from a total of 525 mature sheep 405 from indigenous and 120 from local x Awassi crossbred (135 indigenous from Wogide district and 45 per kebele, 150 indigenous from Borena district 50 per kebele and 240 from Legambo district 120 local x Awassi crossbred from
Chiro about 37.5-75\% Awassi blood level and 120 indigenous sheep from other two kebele). Within each kebele, measurements were made on individual sheep from randomly selected flocks for indigenous sheep. However, for local $\mathrm{x}$ Awassi crossbred sheep, Chiro kebele in Legambo district was purposely selected. Then individual animals were randomly selected from purposely selected flocks until the target number of sample animals was reached. Linear body measurements were made using measuring tape while live body weight is taken using suspended spring balance having $50 \mathrm{~kg}$ capacity with 0.2 $\mathrm{kg}$ precision.

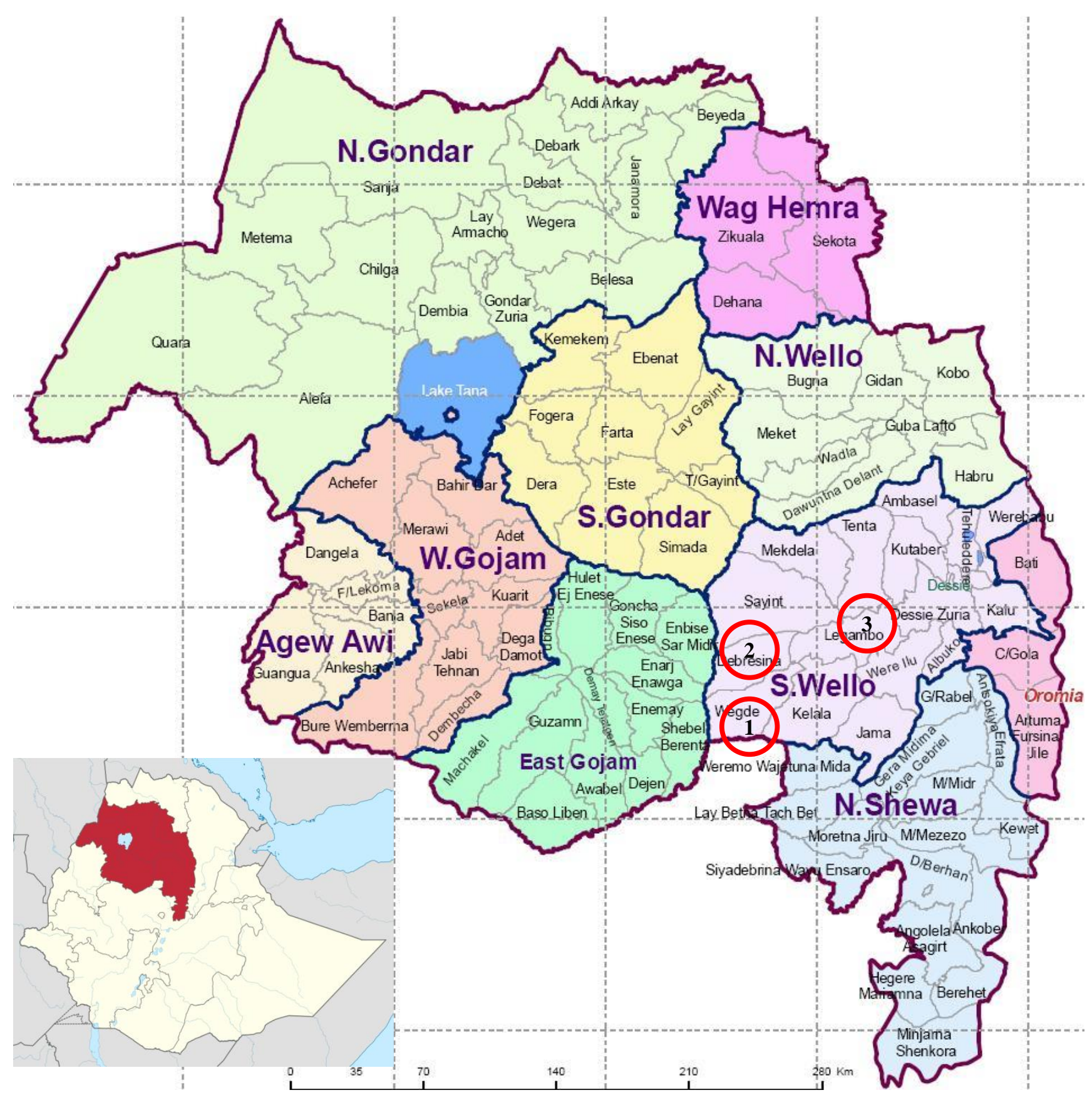

Figure 1. Map of the study areas in South Wollo Zone, Amhara Region, Ethiopia. District of: 1. Wogide (Wegde), 2. Borena (Debresina), 3. Legambo 
Table 1. Description of the Districts of South Wollo, Amhara, Ethiopia

\begin{tabular}{lrrr}
\hline $\begin{array}{l}\text { Study areas } \\
\text { characteristics }\end{array}$ & Wogide & $\begin{array}{c}\text { Districts } \\
\text { Borena }\end{array}$ & Legambo \\
\hline & & & \\
$\begin{array}{l}\text { Distance from Addis } \\
\text { Ababa (km) }\end{array}$ & 594 & 592 & 501 \\
$\begin{array}{l}\text { Distance from Bahir Dar } \\
(\mathrm{km})\end{array}$ & 673 & 671 & 580 \\
Distance from Dessie $(\mathrm{km})$ & 193 & 191 & 100 \\
Altitude (m. asl) & $500-2700$ & $500-3200$ & $1500-3700$ \\
Latitude and longitude & $10^{\circ} 40^{\prime} \mathrm{N}$ & $10^{\circ} 55^{\prime} \mathrm{N}$ & $11^{\circ} 00^{\prime} \mathrm{N}$ \\
& $11^{\circ} 38^{\prime} \mathrm{E}$ & $38^{\circ} 30^{\prime} \mathrm{E}$ & $39^{\circ} 00^{\prime} \mathrm{E}$ \\
Rainfall (mm) & $600-1100$ & $1500-3660$ & $700-1200$ \\
Temperature $\left({ }^{\circ} \mathrm{C}\right)$ & $23^{\circ} \mathrm{c}$ & $16.5^{\circ} \mathrm{c}$ & $13^{\circ} \mathrm{c}$ \\
Area $\left(\mathrm{km}{ }^{2}\right)$ & $1,110.69$ & $1,027.61$ & $1,017.35$ \\
Human population & 151,257 & 158,209 & 165,026 \\
Cattle & 36,684 & 78,533 & 76,464 \\
Sheep & 15,442 & 68,642 & 146,954 \\
Goat & 48,059 & 35,417 & 11,815 \\
Horse & 63 & 1,552 & 6,662 \\
Donkey & 16,045 & 14,171 & 18,769 \\
Mule & 341 & 1.493 & 2,842 \\
Poultry & 47,389 & 73,903 & 74,494 \\
& & & \\
\hline
\end{tabular}

\section{Data collection procedures}

Quantitative traits cover the size and dimensions of animals' bodies or body parts, which are more directly correlated to production traits than qualitative traits. For example, body weight and chest girth are directly related to body size and associated production traits. In general, these variables have a continuous expression. This is because of the numerous genes that determine or influence their expression (FAO 2012). Body Measurements: Body weight, chest girth (CG), body length (BL), wither height (WH), tail length (TL), tail circumference (TC), rump height, ear length, horn length, scrotum circumference (SC) and body condition score (BCS) were measured using tailors measuring tape while weight was measured using suspended spring balance having $50 \mathrm{~kg}$ capacity. Each animal was identified by its sex, dentition and sampling site. Dentition record was included, as this will be the only reliable means to estimate the approximate age of an animal. Ages of the animals were estimated from dentition class following the procedure described by (ESGPIP 2009).

Adult sheep was classified into five age groups; no pair of permanent incisor (0 PPI), 1 pair of permanent incisor (1 PPI), 2 pairs of permanent incisor (2 PP), 3 pairs of permanent incisor (3 PPI) and 4 pairs of permanent incisor (4 PPI) to represent age of fewer than 12 months, 12 to 18 months, 18 to 24 months, 24 to 36 months and more than three years, respectively based on the (ESGPIP 2009). The data collected from each study area were checked for any error and corrected during the study period, coded and entered into the computer for further analysis.

\section{Data management and statistical analysis}

Data collected through body measurement were entered into Microsoft EXCEL 2007, Statistical Package for Social Sciences (SPSS 20 for Windows and SAS 9.1 for
Windows). Preliminary data analyses like homogeneity test, normality test and screening of outliers were employed before conducting the main data analysis.

\section{Morphological and body measurement data}

Data collected on body weight and other body measurements were analyzed separately for each district. Quantitative characters (body weight and linear body measurements) were analyzed using the Generalized Linear Model (GLM) procedures of the Statistical Analysis System (SAS 9.1 2003). Scrotum circumference was analyzed for each breed by fitting age group as fixed factor. Horn was the specific character of male Wollo sheep only so that analysis of horn length was employed for male Wollo sheep only by fitting age group as fixed factor. When analysis of variance declares significance, least-square means were separated using adjusted Tukey-Kramer test.

Models to analyze adult body weight and other linear body measurements except for scrotum circumference and horn length were:

Model 1: Yijk $=\mu+\mathrm{Ai}+\mathrm{Dj}+\mathrm{Sk}+(\mathrm{AxS}) \mathrm{ik}+$ eijk

Where:

Yijkl = the body weight or linear body measurements except scrotum circumference and horn length in the $\mathrm{i}^{\text {th }}$ age group, $\mathrm{j}^{\text {th }}$ district and $k^{\text {th }}$ sex of

$\mu=$ overall mean

$\mathrm{Ai}=$ the effect of $\mathrm{i}^{\text {th }}$ age classes $(i=0$, land $\geq 2)$

$\mathrm{Dj}=$ the effect of $\mathrm{j}^{\text {th }}$ district $(\mathrm{j}$ : Wogide, Borena and Legambo district)

$\mathrm{Sk}=$ the effects of $\mathrm{k}^{\text {th }}$ sex $(\mathrm{k}=$ male, female $)$

$(\mathrm{AxS}) \mathrm{ik}=$ the effect of the interaction of $i$ of age group with $k$ of sex

Eijk $=$ random residual error

Model 2: $Y i j k=\mu+A i+B j+S k+(A x S) i k+e i j k$

Where:

Yijkl = the body weight or linear body measurements except scrotum circumference and horn length in the $i^{\text {th }}$ age group, $\mathrm{j}^{\text {th }}$ breed and $k^{\text {th }}$ sex of

$\mu=$ overall mean

$\mathrm{Ai}=$ the effect of $\mathrm{i}^{\text {th }}$ age classes $(i=0$, land $\geq 2)$

$\mathrm{Bj}=$ the effect of $\mathrm{j}^{\text {th }}$ breed $(\mathrm{j}=$ Indigenous and local $\mathrm{x}$ Awassi crossbred)

$\mathrm{Sk}=$ the effects of $\mathrm{k}^{\text {th }}$ sex $(\mathrm{k}=$ male, female $)$

$(\mathrm{AxS}) \mathrm{ik}=$ the effect of the interaction of $i$ of age group with $k$ of sex

Eijk $=$ random residual error

Model to analyze the scrotum circumference and horn length was:

$Y i j k=\mu+A i+D j+e i j$

Where:

Yijk = Scrotum circumference

$\mu=$ Overall mean

$\mathrm{Ai}=$ the effect of $\mathrm{i}^{\text {th }}$ age classes $(\mathrm{i}=0,1$ and $\geq 2)$ 
$D j=$ the effect of $j^{\text {th }}$ district $(j=$ Wogide, Borena and Legambo district)

Eij= random residual error

\section{Correlation and regression}

Pearson's correlation coefficients for each breed were estimated between body weight and other body measurements within sex (SAS 9.1). Body weight and other body measurements: chest girth (CG), body length $(\mathrm{BL})$, wither height $(\mathrm{WH})$, tail length (TL), body condition score (BCS), tail circumference (TC), ear length (EL) rump height (RH), horn length (HL) and scrotum circumference (SC) were included for males whereas scrotum circumference (SC) was excluded from the analysis of female sheep.

Among the above measurements BL, WH, CG, BCS, TC, TL, RH, EL, HL and SC (for male only) were selected based on their strong correlation with body weight, then body weight was regressed on the body measurements (BL, WH, CG, TL, BCS, TC, RH, EL and HL) for females within each age group using stepwise regression procedure of (SAS 9.1 2003) to determine the best-fitted regression equation for the prediction of body weight from body measurements. Likewise, stepwise regression was also employed for females within each age group by excluding SC from the model. Best-fitted models were selected based on the coefficient of determination $\left(\mathrm{R}^{2}\right), \mathrm{R}^{2}$ change and simplicity of measurement under field conditions. The following models were used for the analysis of multiple linear regressions.

For male:

$\mathrm{Y} j=\alpha+\beta_{1} X_{1}+\beta_{2} X_{2}+\beta_{3} X_{3}+\beta_{4} X_{4}+\beta_{5} X_{5}+\beta_{6} X$ ${ }_{6}+\beta_{7} X_{7}+\beta_{8} X_{8}+\beta_{9} X_{9}+X_{10} \beta_{10}+$ ej

Where:

$Y j=$ the response variable (body weight)

$\alpha=$ the intercept

$X_{1}, X_{2}, X_{3}, X_{4}, X 5, X_{6}, X_{7}, X_{8}, X_{9}$ and $X_{10}$ are the explanatory variables body length, wither height, chest girth, tail length, tail circumference, body condition score, scrotal circumference, rump height, horn length and ear length, respectively.

$\beta_{1}, \beta_{2} \ldots \beta_{9}$ is regression coefficient of the variables $X_{l}$, $X_{2} \ldots X_{10}$

$e j=$ the residual random error

For female:

$Y j=\alpha+\beta 1 X 1+\beta 2 X 2+\beta 3 X 3+\beta 4 X 4+\beta 5 X 5+\beta 6 X 6+$ $\beta 7 X 7+\beta 8 X 8+\beta 9 X 9+\mathrm{ej}$

Where:

$Y j=$ the dependent variable (body weight)

$\alpha=$ the intercept

$X 1, X 2, X 3, X 4, X 5, X 6 ., X 7, X 8$ and $X 9$ are the independent variables; body length, wither height, chest girth, body condition score, tail length, tail circumference, rump height, horn length and ear length, respectively.

$\beta_{1}, \beta_{2} \ldots \beta_{8}$ is regression coefficient of the variable $X_{l}$, $X_{2} \ldots X_{9}$

$\mathrm{ej}=$ the residual random error.

\section{RESULTS AND DISCUSSION}

The main source of variation in live body weight and linear body measurement were district, breed, sex, age group and the interaction of both sex and age group. Information on live body weight and linear measurements of the existing breed types has a vital role in the selection program. Information on body and testicle size of specific sheep breeds at constant age has paramount importance in the selection of genetically superior animals for production and reproduction purposes. Therefore, it is not doubted that live body weight and linear body measurement is playing a crucial role in genetic improvement and selection of specific breeds.

\section{Effect of district, breed, sex, age group and interaction of age group and sex}

\section{District effect}

The least-squares means and standard errors for the effect of district, breed, sex, age group and interaction of age group and sex on body weight and other body measurements are presented in Tables 2 and 3 for indigenous and Awassi crossbred. In this study body weight and most of the linear body measurements (body length, chest girth, wither height and rump height) were significantly affected by the district $(p<0.01)$ whereas, scrotum circumference was not influenced by district $(\mathrm{P}>0.05)$. Alemayehu (2011) and Abera et al. (2016) reported that most of the linear body measurements had significant $(\mathrm{p}<0.05)$ effect on live body weight and linear body measurements across the districts studied. In contrary to the current study, Shibabaw (2012) indicated that district had no effect ( $p>0.05)$ except the body weight which was higher in Metta (29.4 \pm 0.2$)$ than Deder (28.8 \pm 0.2$)$ district in Haragehe highland sheep.

The results of this study revealed that body weight measurement was almost similar for Borena $(25.71 \pm 0.39$ $\mathrm{kg})$ and Wogide sheep $(24.90 \pm 0.38 \mathrm{~kg})$ but higher than indigenous Legambo sheep $(22.19 \pm 0.41 \mathrm{~kg})$. It might be due to a serious problem of feed shortage, high population of sheep per household and management difference in Legambo district rather than Wogide and Borena districts. The body weight of indigenous sheep and local x Awassi crossbred in this study was lower than the Doyogena sheep $(31.64 \pm 0.43 \mathrm{~kg}$ ) (Taye et al. 2016). This might be due to the small size of Wollo sheep.

\section{Breed effect}

Local $\mathrm{x}$ Awassi crossbred had significantly higher values for body weight, body length, chest girth, wither height and rump height $(\mathrm{P}<0.01)$ and scrotal circumference was no significant $(\mathrm{P}>0.05)$ between local $\mathrm{x}$ Awassi crossbred and indigenous sheep in Legambo. The body weight, body length, chest girth, wither height, rump height and scrotum circumference of local $\mathrm{x}$ Awassi crossbred were $28.75 \pm 0.49 \mathrm{~kg}, 60.82 \pm 0.49,72.96 \pm 0.53$, $65.94 \pm 0.43,69.71 \pm 0.46$ and $26.16 \pm 0.93 \mathrm{~cm}$, respectively. Whereas the body weight, body length, chest girth, wither height, rump height and scrotum circumference of 
indigenous sheep were $22.19 \pm 0.41 \mathrm{~kg}, \quad 51.03 \pm 0.41$, $64.16 \pm 0.50,57.60 \pm 0.40,60.67 \pm 0.38$ and $24.57 \pm 0.64 \mathrm{~cm}$, respectively. The result of body weight of local x Awassi crossbred was lower than that of Bonga sheep but higher than Horro sheep (Edea et al. 2009). The result of body weight $(28.75 \mathrm{~kg})$ of local $\mathrm{x}$ Awassi crossbred was lower than pure Awassi $(46.5 \mathrm{~kg}$ ), and chest girth (72.96) in this study also lower than pure Awassi (86.90) (Macedonian 2011). It might be due to the small size of Wollo sheep.

\section{Sex effect}

For indigenous sheep, sex of the sheep had significant $(\mathrm{p}<0.01)$ effect on body weight, chest girth, wither height and rump height. However, body length of indigenous sheep was not affected $(p>0.05)$ by sex of the sheep. This finding is in agreement with Getachew et al. (2009) who reported for Menz and Afar sheep of body weight, chest girth, wither height and rump height had significant $(\mathrm{P}<0.01)$ but body length was not $(\mathrm{P}>0.05)$ by sex of the sheep. Taye et al. (2010) reported that a significant effect of sex on body weight, heart girth, body length and height at wither in Washera sheep and Gebreyowhens and Tesfay (2016) who reported that a significant $(p<0.05)$ effects on body weight and other linear body measurements for Atsbiwonberta district of Tigray Region. However, this study disagrees with Alemayehu (2011) who found the sex of the sheep had no significant $(p>0.05)$ effect on the body weight and other linear measurements. Haylom et al. (2014) also reported that sex has no significant $(p>0.05)$ effect on body weight, heart girth, body length and height at wither in highland sheep found in Atsbiwonberta. The body weight of indigenous rams $(26.09 \pm 0.47 \mathrm{~kg})$ and ewes $(22.46 \pm 0.31 \mathrm{~kg})$ in the current study was lower than those reported for Gozamen, Sinan and Hulet eju districts in East Gojam rams $(30.8 \mathrm{~kg})$ and ewes $(28.3 \mathrm{~kg})$ reported by Abera et al. (2016).

However, the body weight of indigenous rams $(26.09 \pm 0.47)$ and ewes $(22.46 \pm 0.31 \mathrm{~kg})$ in the current study was higher than those reported for Menz rams and ewes, with $22 \mathrm{~kg}$ and $19.3 \mathrm{~kg}$, respectively (Getachew et al. 2009) and Mohammed et al. (2015) who reported $25.86 \pm 0.20 \mathrm{~kg}$ for Gubalafto ram but almost similar for Gubalafto ewe $(22.55 \pm 0.15 \mathrm{~kg})$.

Male sheep were consistently higher in body weight, wither height and rump height $(\mathrm{p}<0.01)$ than females while body length and chest girth were higher in number but not statistically significant. Differences in live weight and most of the body measurements between sexes observed in indigenous showed that these parameters are sexdependent. The body weight and other linear measurements of local $x$ Awassi crossbred were higher than the indigenous sheep that are found in the study areas. This finding is higher than reported by Gebreyowhens and Tesfay (2016) for highland sheep population of Tigray region.

\section{Age effect}

In the highland sheep found in Atsbiwonberta, age has an effect on the live body and linear body measurements (Gebreyowhens and Tesfay 2016). In this study body weight and all the body measurements of indigenous sheep were significantly $(p<0.01)$ affected by age group in the study areas. In these study areas, indigenous breed of body weight and all linear body measurements were increased as the age increased from the youngest ( 0 PPI) to the oldest $(\geq$ 2 PPI).

The report of the current finding is in line to the previous reports of Edea et al. (2009) for Bonga and Horro sheep and Gebreyowhens and Tesfay (2016) who found that as the age of the individual animal advanced, the average values of live body weight, heart girth, body length, and height at wither are significantly $(\mathrm{P}<0.05)$ increased in the highland sheep population in Tigray Region. The current study observed that growth rate from 0PPI to 1PPI was higher compared to that from 1PPI to $\geq 2$ PPI in live body weight of the indigenous sheep population.

\section{Age by sex interaction}

As the age of the male and female sheep advanced, their body size also increased, resulting in male are heavier than female sheep. It is obvious that both sex and age have a synergetic effect on body size of the animal (Gebreyowhens and Tesfay 2016). The interaction of sex and age group was significant $(\mathrm{p}<0.01)$ for body weight, chest girth, wither height and rump height but not significant $(\mathrm{p}>0.05)$ for body length for indigenous sheep. These parameters might not be affected by the sex-age interaction effect.

The current finding in the interaction effect between sex and age is in line to Getachew et al. (2009) for Menz and Afar sheep, Mohammed et al. (2015) for Habru and Gubalafto districts and Gebreyowhens and Tesfay (2016) for Atsbiwonberta district which were significantly $(p<0.05)$ affected body weight, heart girth, wither height and rump height while body length was not affected significantly $(\mathrm{P}>0.05)$. However, previous findings by Abera et al. (2016) reported that age by sex interaction had a significant effect $(\mathrm{p}<0.05)$ for only body weight. In all age groups of indigenous males sheep were heavier $(\mathrm{p}<0.01)$ than females.

Body weight obtained at the OPPI age group of indigenous male and female sheep in this study was lower than that in Mohammed et al. (2015) but at the age of 1PPI and 2PPI of indigenous males was higher, age of 1PPI indigenous females is almost similar, 2PPI higher than that in Mohammed et al. (2015) who reported for Habru and Gubalafto districts. Body weight of in this study of indigenous male and female sheep in all age group is higher than that in Getachew et al. (2009) who reported for male and female Menz sheep.

The overall body weight of indigenous sheep $(24.27 \pm 0.28 \mathrm{~kg})$ in three districts is similar to Mohammed et al. (2015) $(25.51 \pm 2.15 \mathrm{~kg})$ for Habru and Gubalafto districts. The overall scrotum circumference of indigenous sheep is in agreement with Mohammed et al. (2015) for Habru and Gubalafto districts. A significant effect of sex and age of sheep on body weight of sheep is reported by many scholars for different breeds of sheep (Getachew et al. 2009; Edea et al. 2009; Bimerew et al. 2011). 


\section{Correlation between body weight and linear body measurements}

Determining animal live body weight, linear body measurements and their interrelationship and correlation are very important for determining genetic potential, breed standards and improved breeding programs for higher meat production (Younas et al. 2013). Correlation coefficients of live body weight with other quantitative variables for male and female indigenous sheep in three districts and local $\mathrm{x}$ Awassi crossbred are presented in Table 4. All linear body measurements of male indigenous sheep showed very high significant $(\mathrm{p}<0.01)$ associations with body weight positively. Except for horn length $(\mathrm{P}>0.05)$ all linear body measurements of female indigenous sheep showed very high significant $(\mathrm{p}<0.01)$ associations with body weight positively. Among measured linear quantitative variables of indigenous male sheep body length $(r=0.85)$, chest girth $(\mathrm{r}=0.91)$, wither height $(\mathrm{r}=0.88)$ and rump height $(\mathrm{r}=$ 0.87 ) were strongly correlated with the body weight. Among measured linear quantitative variables of indigenous female sheep body length $(r=0.76)$, chest girth $(r=0.85)$ was strongly correlated with body weight.

Among measured linear quantitative variables of local $\mathrm{x}$ Awassi crossbred, male sheep wither height $(r=0.71)$ was strongly correlated with the body weight whereas chest girth $(\mathrm{r}=0.88)$ was correlated with body weight for female sheep. This highest correlation of wither height and chest girth with body weight than other body measurements is in line with other results (Gizaw et al. 2008; Getachew et al. 2009; Alemayehu 2011; Abera et al. 2016). The strong correlation of different measurements with body weight would imply these measurements can be used as indirect selection criteria to improve live weight (Gizaw et al. 2008; Getachew et al. 2009; Abera et al. 2014; Mohammed et al. 2015; Abera et al. 2016; Bireda et al. 2016) or could be used to predict body weight. The high correlation coefficients between body weight and body measurements for males and female suggest that either of these variables or their combination could provide a good estimate for predicting the live weight of sheep from body measurements.

Table 2. Least squares mean \pm standard errors of body weight $(\mathrm{kg})$ and other linear body measurements $(\mathrm{cm})$ for the effects of districts, sex, age group and sex by age group for indigenous sheep in the study areas

\begin{tabular}{|c|c|c|c|c|c|c|c|c|c|c|c|c|}
\hline \multirow{2}{*}{$\begin{array}{l}\text { Effects } \\
\text { levels }\end{array}$} & \multicolumn{2}{|r|}{ BW } & \multicolumn{2}{|r|}{ BL } & \multicolumn{2}{|r|}{ CG } & \multicolumn{2}{|r|}{ WH } & \multicolumn{2}{|r|}{ RH } & \multicolumn{2}{|r|}{ SC } \\
\hline & $\overline{\mathbf{N}}$ & $\mathrm{LSM} \pm \mathrm{SE}$ & $\mathbf{N}$ & LSM \pm SE & $\mathbf{N}$ & LSM + SE & $\mathbf{N}$ & LSM \pm SE & $\mathbf{N}$ & LSM + SE & $\mathbf{N}$ & LSM \pm SE \\
\hline Overall & 405 & $24.27 \pm 0.28$ & 405 & $54.04 \pm 0.28$ & 405 & $68.34 \pm 0.34$ & 405 & $62.16 \pm 0.28$ & 405 & $66.52 \pm 0.26$ & 83 & $24.38 \pm 0.35$ \\
\hline $\mathrm{R}^{2}$ & 405 & 0.51 & 405 & 0.53 & 405 & 0.52 & 405 & 0.55 & 405 & 0.65 & 83 & 0.55 \\
\hline $\mathrm{CV} \%$ & 405 & 16.26 & 405 & 7.11 & 405 & 6.43 & 405 & 6.19 & 405 & 5.50 & 83 & 12.38 \\
\hline Districts & & $* *$ & & $* *$ & & $* *$ & & $* *$ & & $* *$ & & NS \\
\hline Wogide & 135 & $24.90 \pm 0.38 \mathrm{a}$ & 135 & $55.69 \pm 0.38 \mathrm{a}$ & 135 & $70.18 \pm 0.46 a$ & 135 & $63.42 \pm 0.38 b$ & 135 & $69.45 \pm 0.36 \mathrm{a}$ & 30 & $24.74 \pm 0.52$ \\
\hline Borena & 150 & $25.71 \pm 0.39 a$ & 150 & $55.40 \pm 0.39 a$ & 150 & $70.67 \pm 0.47 \mathrm{a}$ & 150 & $65.45 \pm 0.38 \mathrm{a}$ & 150 & $69.44 \pm 0.36 \mathrm{a}$ & 30 & $23.83 \pm 0.54$ \\
\hline Legambo & 120 & $22.19 \pm 0.41 \mathrm{~b}$ & 120 & $51.03 \pm 0.41 \mathrm{~b}$ & 120 & $64.16 \pm 0.50 \mathrm{~b}$ & 120 & $57.60 \pm 0.40 \mathrm{c}$ & 120 & $60.67 \pm 0.38 b$ & 23 & $24.57 \pm 0.64$ \\
\hline Sex & & $* *$ & & NS & & $* *$ & & $* *$ & & $* *$ & $\mathrm{NA}$ & NA \\
\hline Male & 83 & $26.09 \pm 0.47 \mathrm{a}$ & 83 & $54.46 \pm 0.47$ & 83 & $69.50 \pm 0.57 \mathrm{a}$ & 83 & $63.66 \pm 0.46 \mathrm{a}$ & 83 & $68.19 \pm 0.44 \mathrm{a}$ & 83 & $24.38 \pm 0.35$ \\
\hline Female & 322 & $22.46 \pm 0.31 \mathrm{~b}$ & 322 & $53.62 \pm 0.30$ & 322 & $67.17 \pm 0.37 b$ & 322 & $60.64 \pm 0.30 \mathrm{~b}$ & 322 & $64.85 \pm 0.29 b$ & - & - \\
\hline Age group & & $* *$ & & $* *$ & & $* *$ & & $* *$ & & $* *$ & & $* *$ \\
\hline OPPI & 137 & $19 . .65 \pm 0.35 \mathrm{c}$ & 137 & $49.65 \pm 0.35 c$ & 137 & $63.68 \pm 0.43 c$ & 137 & $58.77 \pm 0.35 c$ & 137 & $63.05 \pm 0.33 c$ & 46 & $20.50 \pm 0.42 c$ \\
\hline 1PPI & 46 & $25.00 \pm 0.58 \mathrm{~b}$ & 46 & $55.10 \pm 0.57 \mathrm{~b}$ & 46 & $69.00 \pm 0.70 \mathrm{~b}$ & 46 & $62.77 \pm 0.57 b$ & 46 & $67.23 \pm 0.54 \mathrm{~b}$ & 21 & $24.54 \pm 0.63 b$ \\
\hline$\geq 2 \mathrm{PPI}$ & 222 & $28.17 \pm 0.51 \mathrm{a}$ & 222 & $57.36 \pm 0.50 \mathrm{a}$ & 222 & $72.33 \pm 0.61 \mathrm{a}$ & 222 & $64.93 \pm 0.50 \mathrm{a}$ & 222 & $69.29 \pm 0.47 \mathrm{a}$ & 16 & $28.05 \pm 0.72 \mathrm{a}$ \\
\hline Sex by & & $* *$ & & NS & & $* *$ & & $* *$ & & $* *$ & $\mathrm{NA}$ & NA \\
\hline Male OPPI & 46 & $20.24 \pm 0.57 \mathrm{~cd}$ & 46 & $49.73 \pm 0.57$ & 46 & $63.31 \pm 0.69 c$ & 46 & $59.16 \pm 0.56 \mathrm{de}$ & 46 & $63.78 \pm 0.54 \mathrm{de}$ & - & - \\
\hline Male 1PPI & 21 & $27.72 \pm 0.85 \mathrm{ab}$ & 21 & $55.35 \pm 0.84$ & 21 & $71.26 \pm 1.03 \mathrm{a}$ & 21 & $64.41 \pm 0.84 \mathrm{ab}$ & 21 & $68.89 \pm 0.79 \mathrm{ab}$ & - & - \\
\hline Male $\geq 2$ PPI & 16 & $30.31 \pm 0.98 \mathrm{a}$ & 16 & $58.31 \pm 0.97$ & 16 & $73.94 \pm 1.18 \mathrm{a}$ & 16 & $67.41 \pm 0.96 \mathrm{a}$ & 16 & $71.91 \pm 0.91 \mathrm{a}$ & - & - \\
\hline Female0PPI & 91 & $19.04 \pm 0.41 \mathrm{~d}$ & 91 & $49.58 \pm 0.41$ & 91 & $64.04 \pm 0.49 b c$ & 91 & $58.38 \pm 0.40 \mathrm{e}$ & 91 & $62.32 \pm 0.38 \mathrm{e}$ & - & - \\
\hline Female1PPI & 25 & $22.28 \pm 0.78 c$ & 25 & $54.86 \pm 0.77$ & 25 & $66.75 \pm 0.94 b$ & 25 & $61.13 \pm 0.77 \mathrm{~cd}$ & 25 & $65.57 \pm 0.73 \mathrm{~cd}$ & - & - \\
\hline$\rightarrow 2 P P$ & 20 & $2604+027 \mathrm{~h}$ & 20 & 564 & $206-2-1$ & $7073+023$ & $206-2$ & $6242+027 \mathrm{~b}$ & 206 & $26 \mathrm{bc}-2$ & & \\
\hline
\end{tabular}

$\begin{array}{llllllllll}\text { Female } \geq 2 \text { PPI } 206 & 26.04 \pm 0.27 \mathrm{~b} & 206 & 56.41 \pm 0.27 & 206 & 70.72 \pm 0.33 \mathrm{a} & 206 & 62.42 \pm 0.27 \mathrm{bc} & 206 & 66.67 \pm 0.26 \mathrm{bc}\end{array}$

Note: Means with different superscripts within the same column and class are statistically different. Ns: Non-significant; *significant at 0.05; **significant at 0.01 , NA: none applicable. N: number of sheep, BW: body weight, BL: body length, CG: chest girth, WH: wither height, rump height and scrotum circumference. 0 PPI: 0 pair of permanent incisors; 1PPI: 1 pair of permanent incisor and $\geq 2$ PPI: 2 or more pairs of permanent incisors. LSM: least square mean and SE: standard error. 
Table 3. Least squares mean \pm standard errors of body weight $(\mathrm{kg})$ and other linear body measurements $(\mathrm{cm})$ for the effects of breed, sex, age group and sex by age group for indigenous and local x Awassi crossbreed sheep for Legambo district

\begin{tabular}{|c|c|c|c|c|c|c|c|c|c|c|c|c|}
\hline \multirow{2}{*}{$\begin{array}{l}\text { Effects \& } \\
\text { levels }\end{array}$} & \multicolumn{2}{|r|}{ BW } & \multicolumn{2}{|r|}{ BL } & \multicolumn{2}{|r|}{ CG } & \multicolumn{2}{|r|}{ WH } & \multicolumn{2}{|r|}{ RH } & \multicolumn{2}{|r|}{ SC } \\
\hline & $\mathbf{N}$ & $\mathbf{S M} \pm \mathbf{S E}$ & $\mathbf{N}$ & $\mathrm{LSM} \pm \mathrm{SE}$ & $\mathbf{N}$ & $\mathbf{L S M} \pm \mathbf{S E}$ & $\mathbf{N}$ & LSM \pm SE & $\mathbf{N}$ & LSM \pm SE & $\mathbf{N}$ & LSM \pm SE \\
\hline Overall & 240 & $25.55 \pm 0.41$ & 240 & $56.21 \pm 0.41$ & 240 & $68.57 \pm 0.45$ & 240 & $62.23 \pm 0.36$ & 240 & $65.60 \pm 0.38$ & 46 & $25.95 \pm 0.72$ \\
\hline $\mathrm{R} 2$ & 240 & 0.65 & 240 & 0.70 & 240 & 0.69 & 240 & 0.66 & 240 & 0.67 & 46 & 0.52 \\
\hline $\mathrm{CV} \%$ & 240 & 15.79 & 240 & 7.24 & 240 & 6.36 & 240 & 5.76 & 240 & 5.85 & 46 & 16.40 \\
\hline Breed & & $* *$ & & $* *$ & & $* *$ & & $* *$ & & $* *$ & & NS \\
\hline Indigenous & 120 & $22.19 \pm 0.41 b$ & 120 & $51.03 \pm 0.41 b$ & 120 & $64.16 \pm 0.50 b$ & 120 & $57.60 \pm 0.40 b$ & 120 & $60.67 \pm 0.38 b$ & 23 & $24.57 \pm 0.64$ \\
\hline $\begin{array}{l}\text { Awassi } \\
\text { crossbred }\end{array}$ & 120 & $28.75 \pm 0.49 \mathrm{a}$ & 120 & $60.82 \pm 0.49 a$ & 120 & $72.96 \pm 0.53 \mathrm{a}$ & 120 & $65.94 \pm 0.43 \mathrm{a}$ & 120 & $69.71 \pm 0.46 \mathrm{a}$ & 23 & $26.16 \pm 0.93$ \\
\hline Sex & & $* *$ & & NS & & NS & & $* *$ & & $* *$ & NA & NA \\
\hline Male & 46 & $26.99 \pm 0.74 a$ & 46 & $56.95 \pm 0.75$ & 46 & $69.29 \pm 0.91$ & 46 & $64.41 \pm 0.65 a$ & 46 & $68.01 \pm 0.70 \mathrm{a}$ & 46 & $25.95 \pm 0.72$ \\
\hline Female & 194 & $24.11 \pm 0.34 b$ & 194 & $55.47 \pm 0.35$ & 194 & $67.85 \pm 0.37$ & 194 & $60.06 \pm 0.30 \mathrm{~b}$ & 194 & $63.19 \pm 0.32 b$ & - & - \\
\hline Age group & & $* *$ & & $* *$ & & $* *$ & & $* *$ & & $* *$ & & $* *$ \\
\hline OPPI & 78 & $20.42 \pm 0.48 c$ & 78 & $51.39 \pm 0.48 b$ & 78 & $63.26 \pm 0.52 c$ & 78 & $58.01 \pm 0.42 \mathrm{c}$ & 78 & $61.37 \pm 0.45 c$ & 28 & $20.85 \pm 0.74 b$ \\
\hline 1PPI & 39 & $26.39 \pm 0.68 b$ & 39 & $57.41 \pm 0.69 a$ & 39 & $69.64 \pm 0.74 b$ & 39 & $62.44 \pm 0.60 \mathrm{~b}$ & 39 & $65.43 \pm 0.64 b$ & 13 & $26.65 \pm 1.10 \mathrm{a}$ \\
\hline$\geq 2 \mathrm{PPI}$ & 123 & $29.84 \pm 0.91 \mathrm{a}$ & 123 & $59.83 \pm 0.92 \mathrm{a}$ & 123 & $72.80 \pm 0.99 \mathrm{a}$ & 123 & $66.24 \pm 0.80 \mathrm{a}$ & 123 & $70.00 \pm 0.85 a$ & 5 & $30.34 \pm 1.74 \mathrm{a}$ \\
\hline Sex by age & & NS & & $*$ & & NS & & $* *$ & & $* *$ & NA & NA \\
\hline Male OPPI & 28 & $21.46 \pm 0.75$ & 28 & $51.16 \pm 0.76 b$ & 28 & $63.63 \pm 0.82$ & 28 & $58.49 \pm 0.66 \mathrm{~cd}$ & 28 & $62.41 \pm 0.71 \mathrm{~cd}$ & $1-$ & - \\
\hline Male 1PPI & 13 & $27.08 \pm 1.11$ & 13 & $57.38 \pm 1.12 \mathrm{a}$ & 13 & $70.16 \pm 1.21$ & 13 & $63.19 \pm 0.97 b$ & 13 & $66.19 \pm 1.04 b$ & - & - \\
\hline Male $\geq 2$ PPI & 5 & $32.44 \pm 1.78$ & 5 & $62.32 \pm 1.80 \mathrm{a}$ & 5 & $74.08 \pm 1.94$ & 5 & $71.54 \pm 1.56 \mathrm{a}$ & 5 & $75.42 \pm 1.67 a$ & - & - \\
\hline Female 0PPI & 50 & $19.39 \pm 0.58$ & 50 & $51.63 \pm 0.58 b$ & 50 & $62.89 \pm 0.63$ & 50 & $57.53 \pm 0.50 \mathrm{~d}$ & 50 & $60.33 \pm 0.54 d$ & - & - \\
\hline Female 1PPI & 26 & $25.70 \pm 0.78$ & 26 & $57.45 \pm 0.79 a$ & 26 & $69.13 \pm 0.85$ & 26 & $61.70 \pm 0.89 b c$ & 26 & $64.68 \pm 0.73 b c$ & - & - \\
\hline Female $\geq 2 \mathrm{PPI}$ & 118 & $27.24 \pm 0.37$ & 118 & $57.33 \pm 0.37 \mathrm{a}$ & 118 & $71.52 \pm 0.40$ & 118 & $60.94 \pm 0.32 \mathrm{~cd}$ & 118 & $64.57 \pm 0.35 b c$ & - & - \\
\hline
\end{tabular}

\section{Prediction of body weight from different linear body measurements}

Multiple regression analysis in the study areas is presented in Table 5. Regression analysis is commonly used in animal research to describe quantitative relationships between a response variable and one or more explanatory variables such as body weight and linear body measurements especially when there is no access to weighing equipment (Cankaya 2008). The accuracy of functions used to predict live weight or growth characteristics from live animal measurements is of vast financial contribution to livestock production enterprises. Multiple regression equations were developed for predicting body weight from other linear body measurements. Stepwise regression was carried out for each breed within each sex and age group for each breed by entering all traits at a time for male and by excluding horn length and scrotum circumference for females for selection of independent variables.

In all sex categories of indigenous sheep (for three districts of indigenous) and local $\mathrm{x}$ Awassi crossbred chest girth was consistently selected and entered into the model in step one procedure of stepwise regression due to its larger contribution to the model than other variables. At second step of stepwise regression chest girth and body length were selected to be in the model, at third step 3 independent variables, etc.

The coefficient of determination $\left(\mathrm{R}^{2}\right)$ represents the proportion of the total variability explained by the model.
In most cases chest girth was found to be the most important in accounting large proportion of the changes in body weight, this measurement was reported for Afar and Menz (Getachew et al. 2009), for Bonga and Horro (Edea et al. 2009) and for Gozamen, Sinan and Hulet eju districts (Abera et al. 2016). Chest girth was more reliable in predicting body weight than other linear body measurements at farmer's level when there are no facilities to take the whole measurements.

Scientifically, chest girth, body length, tail circumference, body condition score and wither height were found to have a significant association with body weight for indigenous males which explained the total variability of $92 \%$ to the dependent variable body weight. Similarly, chest girth, body length, body condition score, wither height, rump height and tail length were found to have a significant association with body weight for indigenous females which explained the total variability of $80 \%$ to the dependent variable body weight.

Wither height and body length were found to have a significant association with body weight for local x Awassi crossbred males which explained total variability of $61 \%$ to the dependent variable body weight. Whereas, chest girth and body length had a significant association with body weight for local $x$ Awassi crossbred females which explained the total variability of $80 \%$ to the dependent variable body weight. 
Table 4. Phenotypic correlation between body weight and linear body measurements for indigenous sheep and local x Awassi crossbred above the diagonal are male and below diagonal are female sheep in selected districts

\begin{tabular}{|c|c|c|c|c|c|c|c|c|c|c|c|c|}
\hline Breed & Traits & BCS & BW & BL & CG & WH & TL & TC & $\mathbf{E L}$ & RH & HL & SC \\
\hline \multirow[t]{10}{*}{ Indigenous } & S BCS & & $0.60^{* *}$ & $0.45^{* *}$ & $0.55^{* *}$ & $0.47^{* *}$ & $0.35^{* *}$ & $0.30^{* *}$ & $0.32^{* *}$ & $0.47^{\text {** }}$ & $0.31^{* *}$ & $0.42^{* *}$ \\
\hline & BW & $0.41^{* *}$ & & $0.85^{* *}$ & $0.91^{* *}$ & $0.88^{* *}$ & $0.54^{* *}$ & $0.40^{* *}$ & $0.29^{* *}$ & $0.87^{* *}$ & $0.67^{* *}$ & $0.64^{* * *}$ \\
\hline & BL & $0.19^{* *}$ & $0.76^{* *}$ & & $0.75^{* *}$ & $0.83^{* *}$ & $0.55^{* *}$ & $0.32^{* *}$ & $0.37^{* *}$ & $0.78^{* *}$ & $0.52^{* *}$ & $0.58^{* *}$ \\
\hline & CG & $0.32^{* * *}$ & $0.85^{* *}$ & $0.73^{* *}$ & & $0.85^{* *}$ & $0.50^{* *}$ & $0.30^{* *}$ & $0.28^{* *}$ & $0.88^{* * *}$ & $0.64^{* *}$ & $0.60^{* * *}$ \\
\hline & WH & $0.21^{\text {** }}$ & $0.70^{* *}$ & $0.67^{* * *}$ & $0.74^{* * *}$ & & $0.58^{* *}$ & $0.28^{*}$ & $0.39^{* *}$ & $0.91^{* *}$ & $0.61^{* *}$ & $0.53^{* *}$ \\
\hline & $\mathrm{TL}$ & $0.16^{* *}$ & $0.28^{* *}$ & $0.29^{* *}$ & $0.20^{* *}$ & $0.25^{* *}$ & & $0.25^{*}$ & $0.45^{* *}$ & $0.56^{* *}$ & $0.38^{* *}$ & $0.51^{* *}$ \\
\hline & $\mathrm{TC}$ & $0.22^{* *}$ & $0.27^{* *}$ & $0.17^{* *}$ & $0.27^{* *}$ & $0.24^{* *}$ & $0.10^{\mathrm{NS}}$ & & $0.03^{\mathrm{NS}}$ & $0.29^{* *}$ & $0.47^{* * *}$ & $0.49^{* *}$ \\
\hline & EL & $-0.06^{\mathrm{NS}}$ & $0.26^{* *}$ & $0.34^{* * *}$ & $0.34^{* *}$ & $0.39^{* *}$ & $0.16^{* *}$ & $0.13^{*}$ & & $0.28^{* *}$ & $0.23^{*}$ & $0.27^{*}$ \\
\hline & $\mathrm{RH}$ & $0.11^{*}$ & $0.64^{* *}$ & $0.70^{* *}$ & $0.75^{* *}$ & $0.84^{* *}$ & $0.25^{* *}$ & $0.21^{* *}$ & $0.46^{* *}$ & & $0.62^{* *}$ & $0.53^{* *}$ \\
\hline & HL & $-0.06^{\mathrm{NS}}$ & $0.01^{\mathrm{NS}}$ & $0.02^{\mathrm{NS}}$ & $-0.19^{\mathrm{NS}}$ & $0.05^{\mathrm{NS}}$ & $0.21^{\mathrm{NS}}$ & $0.11^{\mathrm{NS}}$ & $0.30^{\mathrm{NS}}$ & $0.22^{\mathrm{NS}}$ & & $0.52^{* *}$ \\
\hline \multirow{10}{*}{$\begin{array}{l}\text { Local } \\
\text { Awassi } \\
\text { crossbred }\end{array}$} & $\mathbf{x}$ BCS & & $0.54^{* *}$ & $0.40^{\mathrm{NS}}$ & $0.22^{\mathrm{NS}}$ & $0.40^{\mathrm{NS}}$ & $0.38^{\mathrm{NS}}$ & $0.26^{\mathrm{NS}}$ & $0.02^{\mathrm{NS}}$ & $0.38^{\mathrm{NS}}$ & $0.12^{\mathrm{NS}}$ & $-0.12^{\mathrm{NS}}$ \\
\hline & BW & $0.29^{* *}$ & & $0.60^{* *}$ & $0.63^{* *}$ & $0.71^{* *}$ & $0.59^{* *}$ & $0.49^{*}$ & $-0.01^{\mathrm{NS}}$ & $0.61^{* *}$ & $0.51^{*}$ & $0.44^{*}$ \\
\hline & $\mathrm{BL}$ & $0.09^{\mathrm{NS}}$ & $0.68^{* *}$ & & $0.66^{* *}$ & $0.48^{* *}$ & $0.53^{* *}$ & $0.43^{*}$ & $-0.01^{\mathrm{NS}}$ & $0.45^{*}$ & $0.67^{* *}$ & $0.25^{\mathrm{NS}}$ \\
\hline & CG & $0.27^{* *}$ & $0.88^{* *}$ & $0.65^{* *}$ & & $0.65^{* *}$ & 0.39 & $0.31^{\mathrm{NS}}$ & $0.25^{\mathrm{NS}}$ & $0.58^{* *}$ & $0.52^{*}$ & $0.55^{* *}$ \\
\hline & WH & $0.14^{\mathrm{NS}}$ & $0.53^{* *}$ & $0.47^{* * *}$ & $0.62^{* *}$ & & $0.58^{* *}$ & $0.52^{*}$ & $0.13^{\mathrm{NS}}$ & $0.88^{* * *}$ & $0.46^{*}$ & $0.45^{*}$ \\
\hline & $\mathrm{TL}$ & $-0.29^{* *}$ & $-0.01^{\mathrm{NS}}$ & $0.07^{\mathrm{NS}}$ & $0.09^{\mathrm{NS}}$ & $0.14^{\mathrm{NS}}$ & & $0.70^{* *}$ & $-0.38^{\mathrm{NS}}$ & $0.55^{\text {*** }}$ & $0.47^{*}$ & $0.46^{*}$ \\
\hline & $\mathrm{TC}$ & $0.13^{\mathrm{NS}}$ & $0.45^{* *}$ & $0.26^{* *}$ & $0.43^{* *}$ & $0.30^{* *}$ & $0.15^{\mathrm{NS}}$ & & $-0.27^{\mathrm{NS}}$ & $0.46^{*}$ & $0.41^{\mathrm{NS}}$ & $0.43^{*}$ \\
\hline & EL & $0.05^{\mathrm{NS}}$ & $0.44^{* *}$ & $0.31^{* * *}$ & $0.49^{* *}$ & $0.30^{* *}$ & $0.15^{\mathrm{NS}}$ & $0.43^{* *}$ & & $-0.03^{\mathrm{NS}}$ & $-0.28^{\mathrm{NS}}$ & $0.03^{\mathrm{NS}}$ \\
\hline & $\mathrm{RH}$ & $0.07^{\mathrm{NS}}$ & $0.51^{* *}$ & $0.45^{* *}$ & $0.52^{* *}$ & $0.68^{* *}$ & $0.12^{\mathrm{NS}}$ & $0.38^{* *}$ & $0.22^{*}$ & & $0.46^{*}$ & $0.36^{\mathrm{NS}}$ \\
\hline & $\mathrm{HL}$ & $-0.42^{\mathrm{NS}}$ & $0.31^{\mathrm{NS}}$ & $0.38^{\mathrm{NS}}$ & $0.25^{\mathrm{NS}}$ & $0.56^{*}$ & $-0.23^{\mathrm{NS}}$ & $-0.39^{\mathrm{NS}}$ & $0.15^{\mathrm{NS}}$ & $0.26^{\mathrm{NS}}$ & & $0.51^{*}$ \\
\hline
\end{tabular}

Ns: Non significant; *significant at 0.05 ; **significant at 0.01 . BCS: body condition score, BW: body weight, BL: body length, CG: chest girth, WH: wither height, TL= tail length, TC: tail circumference, EL: ear length, RH: rump height, HL: horn length and SC: scrotum circumference

The $\mathrm{R}^{2}$ was the criteria are used to select the model. The $\mathrm{R}^{2}$ always increases as a new variable was added to the model thus we have to consider when new variable is added to the model, which variable will notably increase the $\mathrm{R}^{2}$ change when added to the model. Generally, in most cases where regression analysis is applied, there can be several potential independent variables that could be included in the model. It is often not easy which variables are really needed in the model. The precision of the model becomes less when we use few variables in the model and inclusion of many variables leads to multicollinearity (Getachew et al. 2009).

The addition of more variable under field condition increase error incurred by the individual taking measurements and some variables are more affected by the animal posture so it is difficult to measure such variables accurately. It was recognized that chest girth is among the variables least affected by the animal posture and easy to measure than other measurements like withering height and body length. Thus under field conditions, live weight estimation using chest girth alone would be preferable to combinations with other measurements because of difficulty of the proper animal restraint during measurement.

Regression models for predicting body weight of males and females of indigenous sheep and Awassi crossbred in south Wollo zone selected districts could be based on regression equation;
For indigenous males:

\section{$\mathrm{Y}=-36.21+0.47 \mathrm{CG}+0.26 \mathrm{BL}+0.09 \mathrm{TC}+0.10 \mathrm{BCS}+0.19 \mathrm{WH}$}

where $\mathrm{Y}=$ response variable (body weight) and chest girth, body length, tail circumference, body condition score and wither height are explanatory (independent) variables.

For indigenous female:

$\mathrm{Y}=-29.57+0.58 \mathrm{CG}+0.30 \mathrm{BL}+0.14 \mathrm{BCS}+0.19 \mathrm{WH}+0.19 \mathrm{RH}+0.05 \mathrm{TL}$

where $\mathrm{Y}=$ response variable (body weight) and chest girth, body length, body condition score, wither height, rump height and tail length are explanatory (independent) variables.

For Awassi x local crossbred male:

$$
\mathrm{Y}=-19.04+0.54 \mathrm{WH}+0.37 \mathrm{BL}
$$

where $\mathrm{Y}=$ response variable (body weight) and wither height and body length are explanatory (independent) variables.

For Awassi x local crossbred female

$$
\mathrm{Y}=-44.32+0.77 \mathrm{CG}+0.18 \mathrm{BL}
$$

where $\mathrm{Y}=$ response variable (body weight) and chest girth and body length are explanatory (independent) variables. 
Table 5. Multiple regression analysis of live weight on different linear body measurements for indigenous and local $\mathrm{x}$ Awassi crossbred ram and ewe in the study areas

\begin{tabular}{|c|c|c|c|c|c|c|c|c|c|c|}
\hline Age & Model & Intercept & $\beta_{1}$ & $\boldsymbol{\beta}_{2}$ & $\boldsymbol{\beta}_{3}$ & $\boldsymbol{\beta}_{4}$ & $\beta_{5}$ & $\beta_{6}$ & $\mathbf{R}^{2}$ & $\begin{array}{c}\mathbf{R}^{2} \\
\text { change }\end{array}$ \\
\hline \multicolumn{11}{|c|}{ Indigenous } \\
\hline \multirow[t]{5}{*}{ Male } & CG & $-26.38 \pm 2.54$ & $0.91 \pm 0.04$ & & & & & & 0.83 & 0.00 \\
\hline & $\mathrm{CG}+\mathrm{BL}$ & $-32.78 \pm 2.26$ & $0.64 \pm 0.05$ & $0.37 \pm 0.06$ & & & & & 0.89 & 0.06 \\
\hline & $\mathrm{CG}+\mathrm{BL}+\mathrm{TC}$ & $-34.55 \pm 2.27$ & $0.62 \pm 0.04$ & $0.35 \pm 0.06$ & $0.10 \pm 0.06$ & & & & 0.90 & 0.01 \\
\hline & $\mathrm{CG}+\mathrm{BL}+\mathrm{TC}+\mathrm{BCS}$ & $-34.49 \pm 2.20$ & $0.58 \pm 0.05$ & $0.34 \pm 0.06$ & $0.09 \pm 0.06$ & $0.10 \pm 0.50$ & & & 0.91 & 0.01 \\
\hline & $\mathrm{CG}+\mathrm{BL}+\mathrm{TC}+\mathrm{BCS}+\mathrm{WH}$ & $-36.21 \pm 2.24$ & $0.47 \pm 0.06$ & $0.26 \pm 0.07$ & $0.09 \pm 0.06$ & $0.10 \pm 0.49$ & $0.19 \pm 0.08$ & & 0.92 & 0.01 \\
\hline \multirow[t]{6}{*}{ Female } & CG & $-24.30 \pm 1.69$ & $0.85 \pm 0.02$ & & & & & & 0.72 & 0.00 \\
\hline & $\mathrm{CG}+\mathrm{BL}$ & $-27.29 \pm 1.62$ & $0.64 \pm 0.03$ & $0.29 \pm 0.04$ & & & & & 0.76 & 0.04 \\
\hline & $\mathrm{CG}+\mathrm{BL}+\mathrm{BCS}$ & $-28.08 \pm 1.54$ & $0.57 \pm 0.03$ & $0.31 \pm 0.04$ & $0.17 \pm 0.22$ & & & & 0.79 & 0.03 \\
\hline & $\mathrm{CG}+\mathrm{BL}+\mathrm{BCS}+\mathrm{WH}$ & $-29.33 \pm 1.63$ & $0.52 \pm 0.04$ & $0.28 \pm 0.04$ & $0.17 \pm 0.22$ & $0.09 \pm 0.04$ & & & 0.79 & 0.01 \\
\hline & $\mathrm{CG}+\mathrm{BL}+\mathrm{BCS}+\mathrm{WH}+\mathrm{RH}$ & $-28.68 \pm 1.62$ & $0.57 \pm 0.04$ & $0.31 \pm 0.04$ & $0.15 \pm 0.22$ & $0.19 \pm 0.05$ & $-0.18 \pm 0.05$ & & 0.80 & 0.01 \\
\hline & $\mathrm{CG}+\mathrm{BL}+\mathrm{BCS}+\mathrm{WH}+\mathrm{RH}+\mathrm{TL}$ & $-29.57 \pm 1.67$ & $0.58 \pm 0.04$ & $0.30 \pm 0.04$ & $0.14 \pm 0.22$ & $0.19 \pm 0.05$ & $-0.19 \pm 0.05$ & $0.05 \pm 0.05$ & 0.80 & 0.01 \\
\hline \multicolumn{11}{|c|}{ Local x Awassi crossbred } \\
\hline \multirow[t]{2}{*}{ Male } & WH & $-11.83 \pm 8.69$ & $0.71 \pm 0.13$ & & & & & & 0.50 & 0.00 \\
\hline & $\mathrm{WH}+\mathrm{BL}$ & $-19.04 \pm 8.52$ & $0.54 \pm 0.14$ & $0.37 \pm 0.12$ & & & & & 0.61 & 0.10 \\
\hline \multirow[t]{2}{*}{ Female } & $\mathrm{CG}$ & $-38.77 \pm 3.69$ & $0.88 \pm 0.05$ & & & & & & 0.78 & 0.00 \\
\hline & $\mathrm{CG}+\mathrm{BL}$ & $-44.32 \pm 4.00$ & $0.77 \pm 0.06$ & $0.18 \pm 0.08$ & & & & & 0.80 & 0.02 \\
\hline
\end{tabular}

Note: CG: chest girth, BL: body length, BCS: body condition score, TC: tail circumference, WH: wither height, RH: rump height and TL: tail length

To summarize, the study of on-farm phenotypic characterization of indigenous sheep population has been carried out in South Wollo zone mainly in three districts (Wogide, Borena, and Legambo). In addition, local $\mathrm{x}$ Awassi crossbred sheep were considered in Legambo district only. The results showed there was a variation in body weight and in all linear body measurements in these districts. This might be due to environmental and genotype differences. The result showed presence of good indigenous sheep genetic potential in the study areas. The breed has the potential to improve livelihood and to increase economy of smallholder farmers in the study areas as well as in the surrounding areas. Notable variation among indigenous population was observed. Indigenous populations in Wogide and Borena were found larger in size. Relatively large size sheep population in Wogide and Borena compared to Legambo might be attributed to better feed resources and natural selection under better environment. Community-based crossbreeding which has been implemented Debre Berhan Agricultural Research Center at Chiro village successfully improved size and the productivity of local sheep in the Legambo district. Good phenotypic correlation was observed among body weight and linear body measurements. This would help for body weight prediction as well as using measurements directly to select best animals for future breeding. In this study, local $\mathrm{x}$ Awassi crossbred had significantly higher values for body weight and other linear body measurements than indigenous sheep. In this study, local x Awassi crossbred with indigenous Wollo sheep in Legambo district especially Chiro village was good indicator to improve local sheep through crossbreeding. Thus, strengthening the existing crossbreeding program in Legambo site and scaling out to similar areas in a controlled way is suggested. However, current attempts and interest by the extension to expand crossbreeding in Wogide and Borena areas need to be considered carefully. Such type of approach might not bring attractive benefits rather will dilute such valuable indigenous genetic resources found in the areas. Thus, in-situ conservation and improvement of the indigenous sheep in Wogide and Borena would be crucial before being diluted to the adapted and relatively productive genotype.

\section{ACKNOWLEDGEMENTS}

The authors would like to acknowledge the smallholder farmers of the three districts for their cooperation during data collection. We would like to thank also Ethiopian Biodiversity Institute and Amhara Trade, Industry and Market Development Bureau for funding this research. I am grateful to Debre Berhan Agricultural Research Center for providing permission to work on its Chiro communitybased crossbreeding village in Legambo district.

\section{REFERENCES}

Abera B, Kebede K, Gizaw S. 2014. Indigenous breeding practices and selection criteria of sheep breed in Selale area, central Ethiopia. Intl J Livestock Res 4 (7): 50-56. DOI: 10.5455/ijlr.20140423043726

Abera M, Kebede K, Mengesha Y. 2016. Phenotypic characterization of indigenous sheep types in Northern Ethiopia. J Nat Sci Res 6 (15): 16-27.

Ajmone-Marsan P, Garcia JF, Lenstra JA. 2010. On the origin of cattle: How aurochs became cattle and colonized the world. Evol Anthropol 19: 148-157. DOI: 10.1002/evan.20267

Alemayehu A. 2011. Phenotypic characterization of indigenous sheep types of Dawuro zone and Konta special woreda of SNNPR, Ethiopia. 
[Thesis]. School of Graduate Studies of Haramaya University, Dire Dawa, and Ethiopia.

AMFI. 2010. The potential for high-value livestock indemnity insurance in Ethiopia, Oromia region. Annual report of the Association of Micro Finance Institution.

Asmare S. 2010. Characterization of Sheep Production System and Fattening Practices in Bahir Dar Zuria Woreda. [Thesis]. School of Graduate Studies of Bahir Dar University. Ethiopia.

Bimerow T, Yitayew A, Taye T, Mekuriaw S. 2011. Morphological characteristics of Farta sheep in Amhara region, Ethiopia. Online J Anim Feed Res 1 (6): 299-305

Bireda W, Kebede K, Mekasha Y, Bejano S. 2016. Phenotypic characterization of black head Somali sheep in Gode and Adadile Districts, Ethiopia. Glob Vet 17 (3): 265-270. DOI: 10.5829/idosi.gv.2016.17.03.10568

Cankaya S. 2008. A comparative study of some estimation methods for parameters and effects of outliers in simple regression model for research on small ruminants Ondokuz Mayis University, Biometry and Genetics Unit, Kurupelit/Samsun, Turkey.

CSA [Central Statistics Agency]. 2016. Agricultural sample survey report on livestock and livestock characteristics (private peasant holdings). Volume II, Statistical bulletin, 578, Addis Ababa, Ethiopia.

CSA [Central Statistical Authority]. 2008. Summary and statistical report of the 2007 population and housing census. In: G. o. E. Central Statistical Agency (ed.), Addis Ababa, Ethiopia

Edea Z, Haile A, Tibbo M, Sharma AK, Assefa D, Sölkner J, Wurzinger M. 2009. Morphological characterization of Bonga and Horro indigenous sheep breeds under smallholder conditions in Ethiopia. Ethiopian J Anim Prod 9 (1): 117-133.

ESGPIP [Ethiopia Sheep and Goat Productivity Improvement Program] 2009. Estimation of weight and age of sheep and goats. Technical Bulletin No. 23. http: //www.esgpip.org [October 10, 2015].

FAO [Food and Agriculture Organization of the United Nations]. 2012 Draft Guidance on Phenotypic Characterization of Animal Genetic Resource. Commission on Genetic Resources for Food And Agriculture. Thirteenth Regular Session. FAO, Rome.

FAOSTAT. FAO Statistical database. http://faostat3.fao.org/ faostat gateway/go/to/home/E (October 30, 2014).

Felius M, Theunissen B, Lenstra JA. 2015. On the conservation of cattlethe role of breeds. J Agric Sci 153: 152-162. DOI: $10.1017 / \mathrm{S} 0021859614000124$

Gebreyowhens W, Tesfay Y. 2016. Morphological Characterization of Indigenous Highland Sheep Population of Tigray, Northern Ethiopia. J Nat Sci Res 6 (1): 96-104

Getachew T, Haile A, Tibbo M, A K Sharma, J Sölkner, Wurzinger M 2010. Herd management and breeding practices of sheep owners in a mixed crop-livestock and a pastoral system of Ethiopia. Afr J Agric Res 5 (8): 685-691.

Getachew T, Haile A, Tibbo M, Sharma A, Kifle A, Terefe E, Wurzinger M, Sölkner J. 2009. Morphological characters and body weight of Menz and Afar sheep within their production system. Ethiopian. J Anim Prod 9 (1):-

Getachew T, Haile A, Wurzinger M, Rischkowsky B, Gizaw S, Abebe A, Sölkner J. 2016. Review of sheep crossbreeding based on exotic sires and among indigenous breeds in the tropics: An Ethiopian perspective. Afr J Agric Res 11 (11): 901-911. DOI: 10.5897/AJAR2013.10626

Getachew T, Gizaw S, Wurzinger M, Haile A, Rischkowsky B, Okeyo AM, Sölkner J, Mészáros G. 2015. Survival analysis of genetic and non-genetic factors influencing ewe longevity and lamb survival of Ethiopian sheep breeds. Livestock Sci 176: 22-32. DOI: 10.1016/j.livsci.2015.03.021
Gizaw S, Getachew T. 2009. The Awassi $\times$ Menz sheep crossbreeding project in Ethiopia: achievements, challenges and lessons learned. Proceedings of the mid-term conference of the Ethiopian sheep and goat productivity improvement program (ESGPIP).

Gizaw S, Komen H., Hanote O, Van Arendonk JAM. 2008. Indigenous sheep resources of Ethiopia: types, production systems and farmers preferences. Anim Genet Res Inf 43: 25-39. DOI: $10.1017 / \mathrm{S} 1014233900002704$

Gizaw S, Van Arendonk JAM, Komen H, Windig JJ, Hanotte O. 2007. Population structure, genetic variation and morphological diversity in indigenous sheep of Ethiopia. Anim Genet 38: 621-628. DOI: 10.1111/j.1365-2052.2007.01659.x

Haylom M, Abegaz S, Yoseph M. 2014. Within breed phenotypic diversity of Sokota/Tigray sheep in three selected zones of Tigray, Northern Ethiopia. J Biol Agric Healthcare 4 (17). (Abstract). http: //www.iiste.org/Journals/index.php/JBAH/article/view/15182.

Kosgey IS, Baker RL, Udo HMJ, Var Arendonk JAM. 2006. Successes and failures of small ruminant breeding programs in the tropics: a review. Small Rumin Res 61: 13-28. DOI: 10.1016/j.smallrumres.2005.01.003

Kosgey IS, Okeyo AM. 2007. Genetic improvement of small ruminants in low-input, smallholder production systems: Technical and infrastructural issues. Small Rumin Res 70: 76-88. DOI: 10.1016/j.smallrumres.2007.01.007

Lemma S, Gizaw S, Getachew T, A Abebe. 2014. On-farm productivity performance of purebred local and Awassi x local crossbred sheep. In: Mekuriaw Z, Zeleke G, Yeheyis L (eds) Proceedings of the 6th and 7th Annual Regional Conference on Livestock Completed Research Activities 25-27 January 2012 and 22-24 January 2013, Amhara Agricultural Research Institute, Bahir Dar, Ethiopia. Amhara Agricultural Research Institute ARARI), Bahir Dar, Ethiopia.

Macedonian and Animal Science. 2011. Awassi and its possible rural development role in Africa and Asia. J Macedonian Sci Anim 1 (2): 305-316.

Mohammed T, Kebede K, Mekasha Y, Abera B. 2015. On-farm phenotypic characterization of native sheep types in North Wollo zone, Northern Ethiopia. Dir Res J Agric Food Sci 3 (3): 48-56.

SAS [Statistical Analysis System]. 2003. SAS for Windows, Release 9.1.SAS Institute, Inc., Cary, NC, USA.

Shibabaw W. 2012. On-farm Phenotypic Characterization of Hararghe Highland Sheep and Their Production Practices in Eastern Hararghe Zone, Ethiopia. [Thesis]. School of Graduate Studies of Haramaya University, Ethiopia.

Sowande OS, Sobola OS. 2007. Body measurements of west African dwarf sheep as parameters for estimation of live weight. Trop Anim Health Prod 40 (6): 433-439. DOI: 10.1007/s11250-007-9116-z

SPSS Version. 20.0. 2013. Software Package for Social Sciences for Window.

Taye M, Abebe G, Gizaw S, Lemma S, Mekoya A, Tibbo M. 2010. Traditional management systems and linear body measurements of Washera. sheep in the western highlands of the Amhara National Regional State, Ethiopia. Livestock Research for Rural Development Vol. 22, Article 169. http: //www.lrrd.org/lrrd22/9/taye22169.htm.

Taye M, Yilma M, Rischkowsky B, Dessie T, Okeyo M, Mekuriaw G, Haile A. 2016. Morphological characteristics and linear body measurements of Doyogena sheep in Doyogena district of SNNPR, Ethiopia. Afr J Agric Res 11 (48): 4873-4885. DOI: 10.5897/AJAR2016.11826

Younas U, Abdullah M, Bhatti JA, Pasha TN, Ahmad N, Nasir M, Hussain A. 2013. Inter-relationship of body weight with linear body measurements in Hissardale sheep at different stages of life. J Anim Plant Sci 23 (1): 40-44. 